\title{
A Radical Scandinavian ("Øresundsk") Approach to Inquiring Organizations
}

A Critique of ICT in Knowledge Management

Martina Sophia Lundin, Leif Bloch Rasmussen

Folkuniversitetet, Sweden \& Copenhagen Business School, Denmark

\begin{abstract}
Knowledge Management is taken to be an important part of the development of the informational society. Knowledge however is not a straightforward concept, which can be handled by Management. Knowledge is contrasted to inquiring and learning in order to develop possibilities for Inquiring Organizations. Inquiring Organizations is seen as making better possibilities in the development of the informational society as seen from a Scandinavian point of view. Finally the possibility for Inquiring is contrasted to the possibility at all to speak and write directly on human existence. In that irony plays an important part. The conclusion - if any - must be that knowledge on human existence cannot be developed without Social Dialogue, and this dialogue must forever be a' search for a way of living
\end{abstract}

Key words: aesthetics, art, communication, design, Epistemology, ideal seeking, inquiry, irony, knowledge, leadership, learning, management, social dialogue, sweeping-in process, systems philosophy.

\section{INTRODUCTION}

This paper investigates the possibilities of using the hype of theories and current thinking on Knowledge Management. This way of thinking seems at the moment to dominate theories on ICT, Strategic Business Management and Strategies in Public Administration. These theories seem to be the answer in both American and European philosophy of management in a turbulent, dynamic globalized world. They may even be seen to be the answer to the quest for a change from a material based to a knowledge based economy.

The original version of this chapter was revised: The copyright line was incorrect. This has been corrected. The Erratum to this chapter is available at DOI: 10.1007/978-0-387-35609-9_29 
Therefore it is of utmost importance to develop a critical and social practice of Knowledge Management. The future of human choices on ICT may be based on the ideals and values hidden in Knowledge Management.

Furthermore we take history of epistemology to be a necessary supplement and correction to an understanding and use of theories and practices of Knowledge Management, even - as the sequel will show, to the point abandoning the concept altogether. The very simple reason is that epistemology through the ages has been occupied with a search for knowledge.

However the introduction of historical epistemology reveals a more fundamental concept: Creation of Knowledge or to use the term we prefer: (Design of) Learning and (Design of) Inquiry. It is our contention that even when researchers and practitioners on Knowledge Management put their attention to Learning and Inquiry vital and essential aspects of these concepts are left out.

Two of the most promising theories we take to be exemplified through "The Fifth Discipline" (by Peter Senge) and "The Design of Inquiring Systems" (by Charles West Churchman).

First, they - by intrinsic necessity - introduce new and important concepts, ideals and values. Political, esthetical, ethical, and religious ideals and values, which may be deadly enemies to the goals ("Zweck-Rationalität") and practices of knowledge management.

Second, they introduce learning styles and inquiring modes and moods. These point to the necessity of considering "elusive" concepts like consciousness, unconsciousness, collective unconsciousness, archetypes, extroversion, introversion, thinking and feeling as ways of judgment, sensing and intuition as ways of perception are introduced. Being specific to individual humans and to collective groups they may prove to be contrary to the pledge for rationalistic thinking and acting in corporate and public practice.

In a controversy so exposed - at least in Scandinavia - methods must be found to overcome the hype and the Big Power: one method is the indirect message using irony and humor, another is using violence, a third may be passive resistance, a fourth is feminology and a fifth may be envisioned as The Power of Art, Myth and Story Telling (Adventure). All of these are radical approaches to current theories and practices in the hype and mainstream approaches to ICT in Knowledge Management. Finally we therefore propose a radical, normative approach(es) to ICT in Learning and Inquiry.

Why radical? Why normative? Why Scandinavian the paper hopefully will implicitly show some answers to these "Why's". It's aim is to take the writers and - hopefully - the readers into a search for a way of extracting 
knowledge from hundreds of years of societal philosophy and political thinking into current day practice and into a search for Our Common Future. And then again: Are we radical; are we normative? The search may go on and on.

\section{Method - Learning and Inquiry as a Sweeping-In Process}

This paper is a bricolage ${ }^{18}$ of the impressions and developments we've seen through the learning and working in Scandinavia. It does not, cannot and will not intend to spell out a full-fledged picture, but hopefully it will make our position clear.

We are using an explorative method based on the method of "sweepingin" developed by E.A. Singer during his life-time search for a way of living the most contended life and die the least reluctant death. He tried to imagine and use all the knowledge sought and experienced during our historical time. $\mathrm{He}$ found out that we would search in vain for any absolute truth if it did not have the mark of ideals to be fought for but never attained. These ideals he imagined to be beauty as the ideal of aesthetics, good as the ideal of ethics, truth as the ideal of science. He took spontaneity, belief and love to be the existential teleological fundament for an individual human being and for humanity as a whole in an ever lasting search for meaning and intensity in life. Furthermore he took politics, technology and economy to be means only, never to be part of an ideal.

Churchman (1971, p. 199-200) has expressed the search in the following words:

"Singer made the theme of endless process a central one in his philosophy; his name for the restlessness he had in mind is "contentment". ... What appear to be opposites, the restless and the contented, become the opposite sides of the same idea when we realize that "contentment" comes from Latin continere, to "hold together". The contented life is the complete life, made up of all the aspects of a life that make it meaningful. But to be restful is to establish oneself in only one sector of a life and to ignore the rest. So to be "contented" is to be restless.

But "restless" does not really capture the essence of Singer's idea because it too often connotes pointless, whereas the Singerian inquiring system is above all teleological, a grand teleology with an ethical base."

${ }^{18}$ Bricolage is a term used by Lei-Strauss in explaining his way of writing and imaging complex human matters. It brings bits and pieces together inside a vision of design without pretending to be more than bits and pieces - and - a vision. 
We therefore start with some preliminary concepts and theoretical and practical approaches to our subject matter. Then we challenge these according to any other possible concepts and theoretical and practical approaches.

\section{Inquiry as essence of Knowledge Creation}

We start our journey by following Malhorta (1998) in his evaluation of the promises made by theories on Knowledge Management. Malhorta (1998) express the problems in this way:

"We are observing increasing hype about the wonders delivered by newest information technologies in an era characterized by knowledge as the critical resource for business activity. With the advent of new technologies, such as data mining, intranets, video conferencing, and web casting, several technology vendors are offering such solutions as panaceas for the business challenges of the knowledge era. Trade press coverage of the "productivity paradox" has further added to the speed of the information technology (IT) treadmill by suggesting that increasing investments in new information technologies should somehow result in improved business performance."

Managers need to develop a greater appreciation for their intangible human assets, captive in the minds and experiences of their knowledge workers.

In America John Dewey tells us that we create knowledge from "learning by doing" and Singer/Churchman makes us wonder whether this "doing" may not be embedded in a search of a way of life, in search of a way of knowing. Both parties tell us that we should free ourselves from personal interests and walk on to theoretical and practical knowledge in a societal context. We are not alone and we should certainly not leave it up to ourselves alone in knowledge formation.

In Europe Jürgen Habermas has been working on power-less and imaginative communication as essential for mutual understanding and knowledge formation. In his book Knowledge and Human Interests (1981) he states that there are three human interests related to three ways of creating knowledge, p. 308:

"There are three categories of processes of inquiry for which a specific connection between logical-methodological rules and 
knowledge constitutive interests can be demonstrated. This demonstration is the task of a critical philosophy of science that escapes the snares of positivism. The approach of the empiricalanalytical sciences incorporates a technical cognitive interest; that of the historical-hermeneutic sciences incorporates a practical one; and the approach of critically oriented sciences incorporates the emancipatory cognitive interest ..."

In The Design of Inquiring Systems, C. West Churchman (1971) however identified five traditions of inquiry basic to Western philosophy ascribed to Leibniz and Locke, Kant, Hegel and Singer as "role models" for ways of creating knowledge. They in fact incorporate the three models of inquiry suggested by Habermas. We therefore use them in the sequel.

In short Harrison and Bramson explains these five Inquiring modes (moods) in "The Art of Thinking" 1982 $2^{19}$ :

- The Synthesist (Hegel) sees likenesses in things that appear unalike, seeks conflict and synthesis, is interested in change, gets at underlying assumptions, sees the essence of problems, is speculative - asks what if and why not, and regards data to be meaningless without interpretation.

- The Idealist (Kant) welcomes a broad range of views, seeks ideal solutions, is interested in values, is receptive, and places equal value on data and theory.

- The Pragmatist (Singer) proceeds on the basis of an eclectic view, uses a tactical, incremental approach; and, being innovative and adaptive, is best in complex situations.

- The Analyst (Leibniz) seeks the "one best way," operates with models and formulas, is interested in "scientific solutions," is prescriptive, and prefers data to theory and method.

- The Realist (Locke) relies on "facts" and expert opinion, seeks solutions that meet current needs, is serious about getting concrete results, acts with efficiency and incisive correction, prefers data over theory.

${ }^{19}$ Why not use Chruchman' own account? Because his writings are in the searching mode, and thereby no short-handed versions may be detected. 


\section{FROM LEARNING ORGANIZATIONS TO INQURING ORGANIZATIONS}

If we take these five modes of inquiry to be the art of "a knowledgeable living" for human beings we should be directed towards learning these ways of knowing in different organizational and societal settings - or maybe even on out own. This calls for a way of learning in organizations. Senge outlines five new disciplines that are gradually converging to innovate learning organizations (cited from Kienholz, 1998):

1. Systems Thinking - is a conceptual framework - a body of knowledge and tools - developed over the last 50 years, that serves to make clearer the full patterns of the problems, issues, and situations that confront us. Systems thinking also helps us see how to change them effectively.

2. Personal Mastery - is the discipline of continually clarifying and deepening our personal vision, of focusing our energies, of developing patience, and seeing reality objectively.

3. Mental Models - are deeply ingrained assumptions, generalizations, or even pictures or images that influence our behavior and understanding of the world.

4. Building Shared Vision - is that discipline wherein people are bound together around a common identity and sense of destiny whereby they excel and learn.

5. Team Learning - through dialogue team members suspends assumptions and enters into genuine "thinking together.

A combination then of Peter Senge and Churchman may provide us with a framework for the understanding of "inquiring organizations". A term suggested by Malhorta, Kienholz and Courtney et.al. Table 1 in the appendix summarizes how the five inquiring systems apply to the concepts of the five disciplines of the learning organization as they have been described above.

\section{Leadership and Inquiring Organizations: A Challenge from Scandinavia}

Is it possible to manage learning and inquiry, to manage inquiring organizations as expressed in table 1 above? In two books the Danish philosopher Ole Fogh Kirkeby has shown the fundamental difference between management and leadership. He shows that management is based on a subject-object relationship, where the manager is directing and ordering 
his/her subordinates by way of being superior and the interests of that superior. The opposite of that approach is leadership, where subjects are in dialogue with subject, mutual understanding of mutual interests. To explain management one may think of a circus, where the animals are directed and trained according to the needs of the manager and the public. The metaphor of leadership is people searching together for our common future.

We agree on the Kantian and Hegelian way of inquiry should be at least two answers. Keeping Singer in the background. Furthermore, it is our contention, that this conclusion for finding ways to "overcome" these two problems on learning could be The Social Dimension in The Social Dialogue as expressed in Scandinavia as a response to the European Union pledge for these concepts as cornerstones in the future of Europe.

This suggestion points to the political fact, that the problems and issues on the future of our society and work can only be addressed in The Social Dimension in the Social Dialogue between different social groupings: workers, employers and managers, public authorities, universities and educational institutions, Non Governmental Organizations (NGO's), Individuals

The Social Dialogue is intended to use the strength and potential in a dialogue on equal terms (time, money, power) but on different value-bases and beliefs among interest groups.

Each of these groupings (interest groups, power bases), however difficult they may be to identify, must have their say, even on the potential dissolution of themselves and the creation of new groupings.

The Social Dimension is intended to develop and secure an equal opportunity for all to participate, at work, in political life, in learning life, in leisure. In short in the development of a life-view and in its practical implementation.

In order to facilitate and encourage innovations The Social Dimension and The Social Dialogue we have explored and partly designed a new learning concept and percept ${ }^{20}$ in Denmark and Sweden: "Cross Cultural (Net-)Workers ${ }^{, 21}$. The ingredients may be pictured as follows:

- critical "border crossing" pedagogy

According to Giroux, 1993, p. 28 (cited at length in order to express the full implications of the term border crossing):

"...border crossing pedagogy is attentive to developing a democratic public philosophy that respects the notion of difference as part of a common struggle to extend the quality of public life."

${ }^{20}$ This term is used by Paul Virilio to stress the importance of perception and experiment along with the conceptualizations in the design process. (See Paul Virilio: Cyberworld, Introite!, 1998, p. 31)

${ }^{21}$ This term is an elaboration on Henry A. Giroux's term "cultural worker". 
- $\quad$ ractical use of philosophy

The idea is to use the different paradigms in philosophy (ex. Positivism, Phenomenology, Hermeneutics, Critical Theory, Teleology, Feminology, Existentialism) to identify the basic human conditions behind any strategic school or any strategic thinking. Furthermore the idea is to develop other ways of strategic thinking using different paradigms.

- practical use of ethics

Ethics in organizations is an expression and impression of sensibility towards all parties involved in the strategic decision-making process.

- bottom-up design of the Inquring Organization

This way of thinking is in fact based on de-learning among workers and shop stewards as they are forced to accept a way of learning (individually and collectively) which are based on the premises set up by someone else than himself or herself. In the words of Ove Korsgaard, 1997, this way of enlightenment is coming "from above" and "from outside". He claims the opposite as being the fundamental nature and praxis in Denmark through the creation of unions and the co-operative movement: enlightenment must was created "from inside" and "from below".

- NetWorking and NetMaking

In "The Rise of the Network Society" (Vol. I of "The Information Age", 1999, p. 168) Castells forcefully argue for this solution:

"Networks are the fundamental stuff of which new organizations are and will be made."

- language re-design and re-presentation

All the above mentioned elements are new and experimental in the design of working life, strategic decision-making processes and organizations. The languages used are most often than not related to the specific discipline even when that discipline is called cross disciplinary or trans-disciplinary. These specific languages must be used of course in their own right and in their own domain.

- arts, aesthetics, faith and friendship

Creativity is very much needed in the design process. But even more important the need for courage, experiment, and re-creation. Courage in order to sustain the strategic fight involved in radical change. Experiment in order to try and evaluate new ways of thinking and acting strategically. Re-creation in order to withdraw rests and introspects. 


\section{Starting Point of Inquiry: Irony}

As told by Alfred Jarry in Johan Asplund, 1970:

"Why does every person tell us that a pocket watch is round, which evidently is wrong. Seen in profile it is obviously flat and an elliptic square. So why the hell did we only notice the form when it is time that is important."

In the Øresund-region an American in Sweden has investigated a Dane's development of a method in "inquiry and learning". Though he is using other terms as well as the Dane we feel free to use their joint method as a confirmation of our sweeping in process.

We refer to Michael Strawser's book "Both/And Reading Kierkegaard from Irony to Edification". In this book Michael Strawser shows that the method used by Søren Kierkegaard in his search for a life-view, a way of life, had as its starting point and its: irony. Not as many thinkers would have us believe from doubt and/or wonder. Only through irony could Kierkegaard secure that the reader would not be over-powered by the opinions of the writer. And at the same time the writer could feel free in his writing, as he could not put any pressure, any false life-views, any false ways of living onto the heart and soul of the reader. This is due to the fact, that using irony the speaker, the writer, the sayer does have a firm conviction, that the reader, the partner in the dialogue would be able to hear, see and feel the hidden message.

This may be expressed as follows, Strawser, p. 29:

"In terms of written language, irony occurs when the phenomenon or word is opposed to the essence or meaning. Thus, it follows logically that without "essences" or meanings, irony could not exist. If I suffered the fate of not being able to mean anything, then I could scarcely be able to be ironic. In addition, no form of irony can be directly understood, and this grants a mark of distinction or superiority to the one "who has ears to hear" the ironic communication."

This superiority to the reader, to willing people in a dialogue provides them with the possibility for an authentic life, Strawser, p. 31:

"Irony both provides and clears the way for the authentic human life, and if this authentic life is further labeled Christian, then irony must have some profound relevance for Christianity. Accordingly, then, it is described biblically: "Irony is, as the negative, the way; not the truth, but the way."

A formidable thesis indeed.

But, Kierkegaard would not be the ironist he was had he not put some suggestions to the paper on how to develop indirect ironic messages for 
the mutual dialogue among human beings searching for a life-view: They may be taken to be:

Can this kind of Dialogue be managed? Can it be lead? Can it be supported by ICT? NO! As Kierkegaard is telling us with a glimpse of hope and smile in his eyes. Because knowledge on human existence can only be told indirectly, and it starts with irony.

Thus we may conclude by a parable told by Johannes Climacus using the Kierkegaardian methods expressed by Strawser as maieutic irony, Strawser, p. 128:

"...existence is immediacy and language/thought is mediacy. The two cannot meet, so Climacus is forced to stretch the limits of language to describe existence. An essential feature of exiting is given in a word. That word is pathos (passion)."

In order to bring a person into a passionate state Climacus would "get him seated on a horse and the horse made to take fright and gallop wildly, or better still, for the sake of bringing the passion out, if I could take a man who wanted to arrive at a place as quickly as possible, and hence already had some passion, and could set him astride a horse that could scarcely walk and yet this is what existence is like if one is to become consciously aware of it. Or if a driver were otherwise not especially inclined toward passion, if someone hitched a team of horses to a wagon for him, one of them a Pegasus and the other a worn-out jade, and told him to drive - I think one might succeed. And it is just this that it means to exist, if one is to become conscious of it. Eternity is the winged horse, infinitely fast, and time is a worn-out jade; the existing individual is the driver.""

\section{References}

Alexandersson, Mikael: John Dewey in Vår Tid, Pedagogiske Magasin, April 2000 (in Swedish)

Asplund, Johan: Om undren over samfundet, Reitzel, 1970

Brynjolfsson, Erik, a professor of information systems at MIT Sloan School, notes in Information Week (Sept. 9, 1996):

Castaneda, Carlos: The Teachings of Don Juan, University of California Press, 1968 (Penguin, 1973)

Castells, Manuel: The Rise of the Network Society (Vol. I of "The Information Age, 1999

Churchman, C.West: The Design of Inquring Systems, Basic Books, 1971

Churchman, C.West: The Systems Approach and Its Enemies, Basic Books, 1979

Courtney, James F., Croasdell, David T. \& Paradice, David B.: Inquiring Organizations, Australian Journal of Information Systems, Vol. 6, no. 1, Sept. 1998

Dewey, John: Democracy and Education, McMillan, 1916 (Swedish Translation, 1999)

Estes, Clarissa Pinkola: Women Who Run with Wolves, Rider 1992

Fogh Kierkeby, Ole: Event and Body-Mind, Doctoral Thesis, 1993, (in Danish) 
Fogh Kirkeby, Ole: Philosophy of Leadership, Samfundslitteratur, 1998 (in Danish).

Giroux, Henry: Border Crossings, Routledge, 1993

Gustavson, Bernt: Bildning $i$ Vår Tid, Klim, 1999 (in Swedish 1998)

Habermas, Jürgen: Knowledge and Human Interests, Beacon Press, 1982

Kienholz, Alice: Systems Rethinking: An Inquiring Systems Approach to the Art and Practice of the Learning Organization, Alice Kienholz Associates, Febr. 1999

Korsgaard, Ove: Kampen om Lyset, Gyldendal, 1998 (in Danish)

Malhorta, Yogesh: Knowledge Management in Inquring Organizations, Proceedings of $3^{\text {rd }}$ Americas Conference on Information Systems (Philosophy of Information Systems Mine Track), Indianapolis, IN, August 15-17, 1997, pp. 293-5

Malhorta, Yogesh: Knowledge Management for the New World of Business, TOOLS@WORK: Deciphering the Knowledge Management Hype' in the Journal for Quality \& Participation special issue on Learning and Information Management, Vol. 21, no. 4, July/August 1998, pp. 58-60

Manville, Brook, director of knowledge management at the consulting firm McKinsey \& Company in Boston

Singer, E.A.: In Search of a Way of Life, Columbia University Press, 1948

Maslow, Abraham: The Farther Reaches of Human Nature, Pelican Books, 1973

Mintzberg, H.: Strategy Safari, Prentice.Hall, 1998

Nonaka, I \& Takeuchi, H: The Knowledge-Creating Company, Oxford University Press, 1995

Strassmann, Paul: The Squandered Computer (Economic Press, 1997)

Strawser, Michael: Both/And Reading Kierkegaard from Irony to Edification, Fordham, 1998:

Ole Thyssen: Værdiledelse, Gyldendal, 1997 (in Danish)

Virilio, Paul: Cyberworld, Introite!, 1998

Yeats, W.B.: The Works of W.B.Yeats, Wordsworth Poetry Library, 1994 


\section{Appendix}

\begin{tabular}{|c|c|c|c|c|c|}
\hline & Synthesist & Idealist & Pragmatist & Analyst & Realist \\
\hline $\begin{array}{l}\text { Systems } \\
\text { Thinking }\end{array}$ & $\begin{array}{l}\text { Mental Models } \\
\text { Identifying the } \\
\text { Real problem } \\
\text { vs. the apparent } \\
\text { problem } \\
\text { Balancing loops } \\
\text { (thesis- } \\
\text { antithesis- } \\
\text { synthesis) }\end{array}$ & \begin{tabular}{|l|} 
Systems \\
Understands \\
relational logic \\
basic to \\
Systems \\
Thinking \\
\end{tabular} & 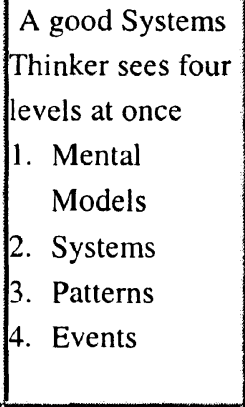 & $\begin{array}{l}\text { Patterns } \\
\text { Reinforcing } \\
\text { Loop } \\
\text { exponential } \\
\text { process (needs } \\
\text { more data ) }\end{array}$ & $\begin{array}{l}\text { Events Single } \\
\text { Loop } \\
\text { Processing } \\
\text { (arithmetic } \\
\text { process) } \\
\text { (simple cause } \\
\text { and effect) }\end{array}$ \\
\hline $\begin{array}{l}\text { Personal } \\
\text { Mastery }\end{array}$ & $\begin{array}{l}\text { Focus on } \\
\text { underlying } \\
\text { assumptions } \\
\text { Focus our } \\
\text { energies }\end{array}$ & $\begin{array}{l}\text { Continually } \\
\text { clarifying and } \\
\text { deepening our } \\
\text { personal vision } \\
\text { Developing } \\
\text { patience }\end{array}$ & $\begin{array}{l}\text { Mastery of each } \\
\text { inquiring system } \\
\text { The Master is the } \\
\text { one who can } \\
\text { change at will to } \\
\text { be situationally } \\
\text { responsive }\end{array}$ & $\begin{array}{l}\text { Developing } \\
\text { patience } \\
\text { Seeing reality } \\
\text { objectively }\end{array}$ & $\begin{array}{l}\text { Focusing our } \\
\text { energies } \\
\text { Seeing reality } \\
\text { objectively }\end{array}$ \\
\hline $\begin{array}{l}\text { Mental } \\
\text { Models }\end{array}$ & $\begin{array}{l}\text { Inquiry } \\
\text { Fundamental } \\
\text { purpose is to } \\
\text { surface mental } \\
\text { models - so we } \\
\text { can talk about } \\
\text { them and } \\
\text { improve them } \\
\text { The Left-Hand } \\
\text { Column }\end{array}$ & $\begin{array}{l}\text { Inquiry } \\
\text { Reflection }\end{array}$ & $\begin{array}{l}\text { Flex to balance } \\
\text { inquiry and } \\
\text { advocacy }\end{array}$ & $\begin{array}{l}\text { Advocacy } \\
\text { Reflection }\end{array}$ & $\begin{array}{l}\text { Advocacy } \\
\text { Ladder of } \\
\text { Inference }\end{array}$ \\
\hline $\begin{array}{l}\text { Building } \\
\text { Shared } \\
\text { Vision }\end{array}$ & $\begin{array}{l}\text { Purpose or } \\
\text { mission Values }\end{array}$ & $\begin{array}{l}\text { Visioning High } \\
\text { Standards } \\
\text { Long-range } \\
\text { goals Values }\end{array}$ & $\begin{array}{l}\text { Goal achievement } \\
\text { (tactical } \\
\text { approach) }\end{array}$ & $\begin{array}{l}\text { Method- } \\
\text { oriented to } \\
\text { achieve goals } \\
\text { Logic and } \\
\text { sequence }\end{array}$ & $\begin{array}{l}\text { Short-range } \\
\text { goals }\end{array}$ \\
\hline $\begin{array}{l}\text { Team } \\
\text { Learning }\end{array}$ & $\begin{array}{l}\text { Dialogue } \\
\text { (suspend } \\
\text { assumptions) }\end{array}$ & $\begin{array}{l}\text { Dialogue } \\
\text { (thinking } \\
\text { together) }\end{array}$ & $\begin{array}{l}\text { Coordinated } \\
\text { patterns of action }\end{array}$ & $\begin{array}{l}\text { S<--.-->A } \\
\text { order out of } \\
\text { chaos }\end{array}$ & Consensus \\
\hline
\end{tabular}

Table 1. Applications of the Five Inquiring Systems to the Five Disciplines of the Learning Organization Adopted from Kienholz (1998) 